\title{
Diuretic effect of chloroform seed extract of Moringa oleifera (Linn.) in Wistar rats
}

\author{
Hema Senthil Kumar ${ }^{1}$, Lourdu Jafrin A. ${ }^{2} *$
}

${ }^{1}$ Department of Pharmacology, Government Sivagangai Medical College, Sivagangai, Tamil Nadu, India

${ }^{2}$ Department of Pharmacology, Indira Gandhi Medical College and Research Institute,

Pondicherry, India

Received: 07 September 2016

Revised: 08 September 2016

Accepted: 12 October 2016

\section{*Correspondence to:}

Dr. Lourdu Jafrin A.,

Email: hiwedz@gmail.com

Copyright: (C) the author(s), publisher and licensee Medip Academy. This is an openaccess article distributed under the terms of the Creative Commons Attribution NonCommercial License, which permits unrestricted noncommercial use, distribution, and reproduction in any medium, provided the original work is properly cited

\begin{abstract}
Background: Diuretics are widely prescribed group of drugs for mobilizing oedema in a variety of clinical situations, including hypertension, heart failure, renal failure, nephrotic syndrome and cirrhosis. Problems like drug resistance, adverse drug reactions and emerging newer diseases, have necessitated research on the vast untapped potential of herbals as potent drugs. Hence in this study an attempt has been made to evaluate the diuretic property of Moringa oleifera.

Methods: Twenty-four adult wistar rats of either sex were divided into four group of six each and they were fasted for 18 hours. Group I received normal feed and water ad libitum. Group IIa received frusemide $1 \mathrm{mg} / \mathrm{kg}$, Group IIb received thiazide $2.5 \mathrm{mg} / \mathrm{kg}$ and Group III received chloroform extract of Moringa oleifera seed $(1000 \mathrm{mg} / \mathrm{kg})$ orally. The diuretic response was assessed by the increase in urine volume and urinary electrolytes.

Results: The analysis showed an increase in urine volume in the groups IIa, IIb and III.

Conclusions: The observations of the present study showed, the total volume of urine, natriuretic, kaliuretic effect exerted by the plant extract was similar to that of hydrochlorothiazide (moderate efficacy diuretic).
\end{abstract}

Keywords: Diuretics, Chloroform, Moringa oleifera, Wistar rats

\section{INTRODUCTION}

Diuretics remain one of the most widely prescribed group of drugs for a variety of clinical situations, including hypertension, heart failure, renal failure, nephrotic syndrome and cirrhosis after their introduction about forty years ago. ${ }^{1}$ The common basic pathology in all these conditions being the retention of excessive volume of fluid in the interstitial compartment and is invariably associated with renal sodium retention resulting in oedema.

Three fundamental strategies exist for mobilizing oedema: ${ }^{2}$

1. Correction of underlying disease

2. Restriction of $\mathrm{Na}^{+}$intake

3. Administration of diuretics
Diuretics remain the cornerstone for the treatment of oedema by increasing the rate of urine flow and sodium excretion and are used to adjust the volume and composition of body fluids. ${ }^{3}$

Many diuretic agents like loop diuretics, thiazides, amiloride and triamterene, exert their effects on specific membrane transport protein in the luminal surface of renal tubular epithelial cells. Other diuretics exert osmotic effects by preventing water reabsorption (mannitol), inhibiting carbonic anhydrase enzymes (acetazolamide), acting on hormonal receptors in renal epithelial cells (spironolactone). Most diuretics act up on a single anatomic segment of the nephron. The action of each diuretic agent can be best understood in relation to its site of action in the nephron and the normal physiology of the segment, because the segments have distinctive transport functions. ${ }^{4}$ 
Problems like drug resistance, adverse effects with available drugs and emerging newer diseases where no medicines are available, have stimulated, a striking increase in the use of herbals in both developing and developed countries due to their natural origin and minimal (or) no side effects. The world over, the pharmaceutical companies and research organization are focusing on the vast untapped potential of herbals as potent drugs. ${ }^{5}$

Plants are a rich source of a variety of chemicals with nutritive and therapeutic properties. All plants produce chemical compounds as a part of their normal metabolic activities. There are primary metabolites and secondary metabolites. Secondary metabolites have therapeutic actions in humans, which can be refined to produce drugs.

Many herbal remedies are being used for oedematous conditions. Among them Moringa oleifera was found to have diuretic property along with antispasmodic, antiulcer, anti-inflammatory, hypoglycemic effects, antidislipidemic, antioxidant, antihypertensive, immunomodulatory, chemo protective, radio protective, antipyretic, antiepileptic, antitumor, antibacterial, and antifungal activities which have been reported in literature. ${ }^{6,7}$ Hence, in this present study an attempt has been made to evaluate the diuretic property of Moringa oleifera.

\section{METHODS}

This study was carried out in the central animal house, institute of pharmacology, Madurai Medical College (MMC), Madurai. It was an experimental study conducted for a period of six months from October to March 2007. Ethical clearance was obtained from the institutional ethical committee, MMC, Madurai.

Table 1: Various groups and its diuretic effects.

\begin{tabular}{|lll|}
\hline Group & Category & $\begin{array}{l}\text { Diuretic effect } \\
\text { (drugs administered) }\end{array}$ \\
\hline I $(\mathrm{n}=6)$ & Control & Normal Feed and water \\
\hline II a $(\mathrm{n}=6)$ & Standard I & $\begin{array}{l}\text { Frusemide } \\
1 \mathrm{mg} / \mathrm{kg} \text { normal feed and } \\
\text { water }\end{array}$ \\
\hline II b $(\mathrm{n}=6)$ & Standard II & $\begin{array}{l}\text { HCT } 2.5 \mathrm{mg} / \mathrm{kg} \text { normal } \\
\text { feed and water }\end{array}$ \\
\hline III $(\mathrm{n}=6)$ & Test & $\begin{array}{l}\text { Chloroform extract }(\mathrm{seed}) \\
1000 \mathrm{mg} / \mathrm{kg} \text { normal feed } \\
\text { and water }\end{array}$ \\
\hline
\end{tabular}

\section{Experimental animals}

Albino rats ${ }^{8}$

Healthy adult wistar rats, 6-8 months old, weighing around 200 to $250 \mathrm{gm}$ of either sex were used. The animals were inbred colony maintained in the central animal house, MMC. They were fed with commercially available standard pellet diet obtained from Amrut feeds, Pranav agro industries limited and water ad libitum.

\section{Drugs and chemicals}

\section{Preparation of Extract of Moringa oleifera ${ }^{9}$}

The seeds of Moringa oleifera were collected and dried in shade for 10 days. It was then coarsely powdered. 200 gm of the powdered seed was soaked in sufficient quantity of chloroform overnight. The contents were transferred to a soxhelt apparatus and extracted for about two hours using hot water bath. The process was repeated several times with fresh seed powder to get sufficient quantities of an extract. The semisolid extract obtained was weighed accurately and utilized for experimental studies. The extract was dissolved in distilled water to yield the required concentration. The dose of the extract was $1000 \mathrm{mg} / \mathrm{kg}$ of body weight.

\section{Hydrochlorothiazide ${ }^{10,11}$}

Tablet hydrochlorothiazide $25 \mathrm{mg}$ was powdered and mixed with $10 \mathrm{ml}$ of distilled water and the suspension prepared to provide $2.5 \mathrm{mg} / \mathrm{ml}$ and it was administered orally at the dose of $2.5 \mathrm{mg} / \mathrm{kg}$ of body weight.

\section{Diuretic effect}

24 albino rats weighing $200-250$ grams of either sex were divided into four groups of 6 each and they were fasted for 18 hours. Group I (Control) received normal feed and water. Group II a (Standard 1) received Frusemide $1 \mathrm{mg} / \mathrm{kg}$ Group IIb (Standard 2) received Thiazide $2.5 \mathrm{mg} / \mathrm{kg}$. Group III (Test) received a chloroform extract of Moringa oleifera seed (1000 $\mathrm{mg} / \mathrm{kg}$ ). All drugs were administered orally. After 24 hours, urine output and electrolytes were assessed for diuretic efficacy. Metabolic cages were used in the analysis of diuretic effect.

\section{RESULTS}

Table 2: Analysis of urinary volume.

\begin{tabular}{|lll|}
\hline & Group & Volume of urine $(\mathrm{ml} / 24$ hours $)$ \\
\hline I & Control & $4.98 \pm 0.26$ \\
\hline IIa & Standard I & $9.4 \pm 0.39$ \\
\hline IIb & Standard II & $8.07 \pm 0.27$ \\
\hline III & Test & $7.72 \pm 0.25$ \\
\hline
\end{tabular}

Group III vs Group I, IIa and IIb - p <0.001, <0.001 and $<0.05$ respectively.

24 adult albino rats weighing 200-250 gms of either sex were divided into four groups of six each. Every day the animals were assessed after the administration of drugs. On close follow up of the animals which received 
hydrochloro thiazide, Frusemide and chloroform extract of Moringa oleifera, did not show any behavioural abnormalities (or) weight loss. These indicated that the extract did not have any systemic toxicity.

Table 3: Analysis of urinary pH.

\begin{tabular}{|lll|}
\hline & Group & Volume of urine $(\mathrm{ml} / 24$ hours $)$ \\
\hline I & Control & $7.1 \pm 0.06$ \\
\hline IIa & Standard I & $7.6 \pm 0.06$ \\
\hline IIb & Standard II & $8.17 \pm 0.05$ \\
\hline III & Test & $9 \pm 0.06$ \\
\hline
\end{tabular}

Group III vs Group I, IIa and IIb $-\mathrm{p}<0.001,<0.001$ and $<0.01$ respectively.

Table 4: Analysis of urinary specific gravity and albumin.

\begin{tabular}{|llll|}
\hline Group & Specific gravity & $\begin{array}{l}\text { Albumin } \\
\text { mg/dl }\end{array}$ \\
\hline I & Control & $1.011 \pm 0.0009$ & $20 \pm 0.63$ \\
\hline IIa & Standard I & $1.011 \pm 0.0006$ & $20 \pm 0.53$ \\
\hline IIb & $\begin{array}{l}\text { Standard } \\
\text { II }\end{array}$ & $1.011 \pm 0.0003$ & $20 \pm 0.63$ \\
\hline III & Test & $1.011 \pm 0.0008$ & $20 \pm 0.43$ \\
\hline
\end{tabular}

Group III vs Group I, IIa and IIb; p >0.05.

\section{Diuretic effect}

The diuretic effect of control, standard I and II and the extract were estimated using metabolic cage and the results were statistically analysed by using a student's unpaired 't' test.

Table 5: Analysis of urinary electrolytes.

\begin{tabular}{|lllll|}
\hline & Group & $\begin{array}{l}\text { Urinary } \text { electrolytes } \\
\text { Sodium } \\
\text { meq/1 }\end{array}$ & $\begin{array}{l}\text { Potassium } \\
\text { meq/1 }\end{array}$ & $\begin{array}{l}\text { Chloride } \\
\text { meq/1 }\end{array}$ \\
\hline \multirow{2}{*}{ I } & \multirow{2}{*}{ Control } & $\begin{array}{l}70.62 \pm \\
0.29\end{array}$ & $\begin{array}{l}57.12 \pm \\
0.23\end{array}$ & $\begin{array}{l}90.92 \pm \\
0.56\end{array}$ \\
\hline \multirow{2}{*}{ IIa } & Standard & $118.25 \pm$ & $81.15 \pm$ & $120.08 \pm$ \\
& I & 0.105 & 0.27 & 0.68 \\
\hline \multirow{2}{*}{ IIb } & Standard & $106.95 \pm$ & $76.15 \pm$ & $108.22 \pm$ \\
& II & 0.27 & 0.21 & 0.50 \\
\hline \multirow{2}{*}{ III } & \multirow{2}{*}{ Test } & $105.13 \pm$ & $74.2 \pm 0.35$ & $102.43 \pm$ \\
& & 0.29 & 0.56 \\
\hline
\end{tabular}

Sodium: Group III vs Group I, IIa and IIb; $\mathrm{p}<0.001,<0.001$, $>0.05$ respectively; Potassium: Group III vs Group I, IIa and IIb; $\mathrm{p}<0.001,<0.001,>0.05$ respectively; Chloride: Group III vs Group I, IIa and IIb; p <0.001.

\section{Urine volume}

The mean 24 hour urinary volume in Group I (control), Group IIa (Standard I), Group IIb (Standard II) and Group III (Extract) were 4.98 $\pm 0.26,9.4 \pm 0.39,8.07 \pm 0.27$ and $7.72 \pm 0.25 \mathrm{ml}$ respectively. There was a highly significant increase in urinary volume in groups which received standard drugs and the extract when compared to control $(\mathrm{p}<0.001)$.

When the urinary volume of the extract was compared with the standard I (Frusemide) it was highly significant ( $\mathrm{p}<0.001)$ and with standard II (hydrochloro thiazide) it was significant $(\mathrm{p}<0.05)$ (Table 1).

\section{PH}

The mean $\mathrm{pH}$ in Group I, Group IIa, IIb and Group III after 24 hours was $7.1 \pm 0.06,7.6 \pm 0.06,8.17 \pm 0.05$ and $9 \pm 0.06$ respectively. There was a highly significant increase in urinary $\mathrm{pH}$ in groups which received standard II (hydrochloro thiazide) and the extract when compared to control $(\mathrm{p}<0.001)$.

When the urinary $\mathrm{pH}$ of the extract was compared with the standard I (frusemide) it was highly significant ( $p$ $<0.001$ ) and with standard II (hydrochloro thiazide) it was moderately significant $(\mathrm{p}<0.01)$ (Table 2).

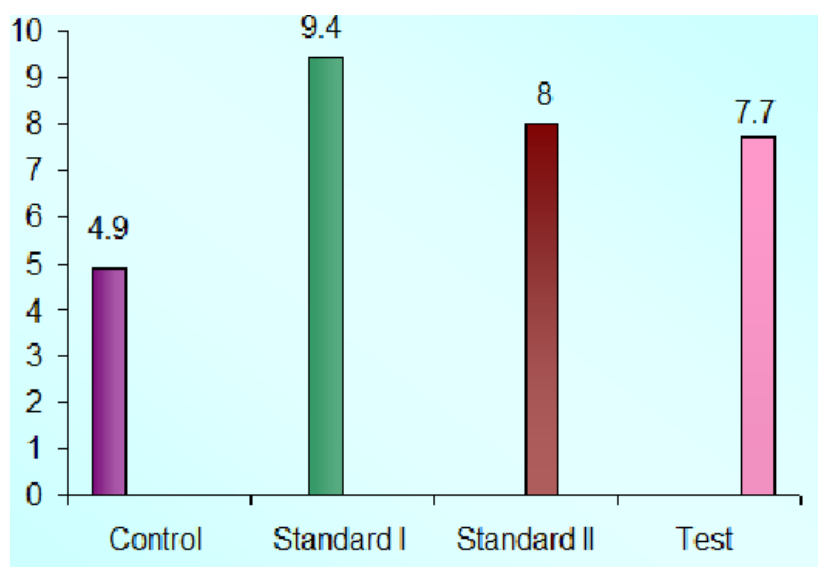

Figure 1: Urine output.

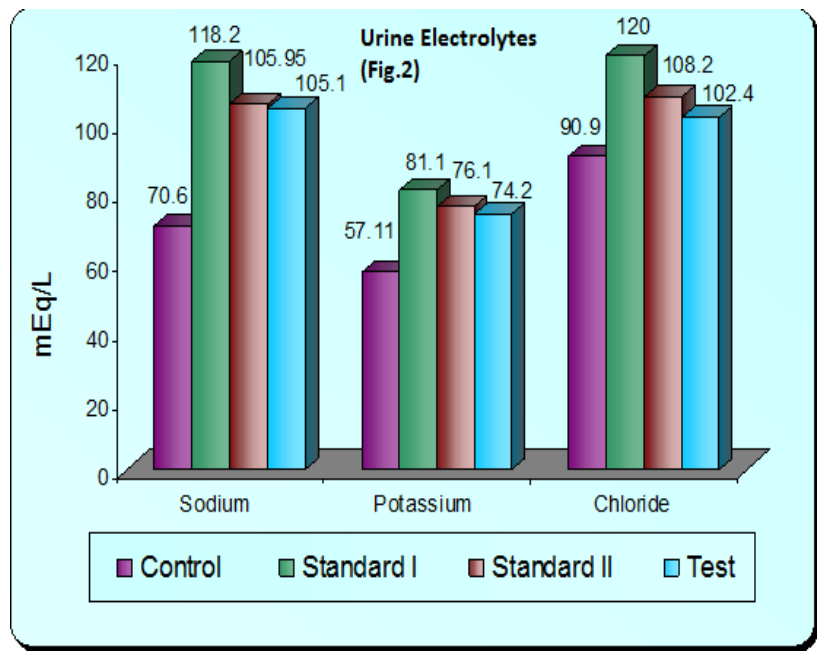

Figure 2: Urine electrolytes. 


\section{Specific gravity}

No significant change in urinary specific gravity and albumin were noted in Group IIa, Group IIb and Group III after 24 hours $(\mathrm{p}>0.05)$ (Table 3).

\section{Analysis of urinary electrolytes}

\section{a. Sodium}

The mean urinary sodium level in Group I, Group II a, $\mathrm{IIb}$ and Group III after 24 hours were $70.62 \pm 0.29$, $118.25 \pm 0.105, \quad 106.95 \pm 0.27$ and $105.13 \pm 0.29 \mathrm{meq} / \mathrm{l}$ respectively. There was a highly significant increase in urinary sodium in groups which received standard drugs and the extract when compared to control ( $\mathrm{p}<0.001)$.

When the urinary sodium of the extract was compared with the standard I (frusemide), it was highly significant $(p<0.001)$ and with standard II (hydrochloro thiazide) it was not significant $(\mathrm{p}>0.05)$ (Table 4$)$.

\section{b. Potassium}

The mean urinary potassium levels in Group I, Group IIa, IIb and Group III after 24 hours were $57.12 \pm 0.23,81.15 \pm 0.27,76.15 \pm 0.21$ and $74.2 \pm 0.35 \mathrm{meq} / 1$ respectively. There was a highly significant increase in urinary potassium in groups which received standard drugs and the extract when compared to control ( $\mathrm{p}<0.001)$.

When the urinary potassium of the extract was compared with the standard I (frusemide), it was highly significant ( $\mathrm{p}<0.001$ ) and with standard II (hydrochloro thiazide) it was not significant ( $p>0.05$ ) (Table 4).

\section{c. Chloride}

The mean urinary chloride levels in Group I, Group IIa, $\mathrm{IIb}$ and Group III after 24 hours were $90.92 \pm 0.56$, $120.08 \pm 0.68, \quad 108.22 \pm 0.50$ and $102.43 \pm 0.56 \mathrm{meq} / \mathrm{l}$ respectively. There was a highly significant increase in urinary chloride in groups which received standard drugs and the extract when compared to control ( $\mathrm{p}<0.001)$.

When the urinary chloride of the extract was compared with the standard I (frusemide) and standard II (hydrochloro thiazide) it was highly significant ( $\mathrm{p}$ $<0.001$ ) (Table 4). Thus the extract of Moringa oleifera (seed) showed significant diuretic, natriuretic and kaliuretic effects.

\section{DISCUSSION}

Diuretics are considered as the ideal pharmacotherapeutic agents for the correction of excess sodium and water load. Moringa oleifera (Drumstick) commonly used and widely cultivated perennial tree has both diuretic effect in addition to other properties ${ }^{12}$.
In this present study, diuretic property of Moringa oleifera was compared with standard drugs. The observations emanated in the present study indicated that the total volume of urine and urinary excretion of sodium, potassium, and chloride were significantly increased in groups which received standard drugs and the extract (Group IIa + IIb and Group III). The possible explanation for significant sodium, potassium, chloride excretions are

- Sodium excretion is always associated with water excretion. ${ }^{13}$

- The urinary chloride excretion could be attributable to sodium and potassium excretion.

Interestingly, the urinary $\mathrm{pH}$ in groups which received hydrochloro thiazide and the extract, showed significant alteration in $\mathrm{pH}$ (alkaline $\mathrm{pH}$ ).

There was no alteration in the urinary specific gravity and the albumin content in Group IIa, Group IIb and Group III. Physiologically, albuminuria indicates glomerular pathology or injury. Urine specific gravity depends upon the tubular system of the nephron during physiological situations. As albuminuria and alteration in specific gravity were not noticed in animals which received standard drugs and the extract (Group IIa + IIb and Group III), it is likely that the plant extract is safe. From the above data the effect of the extract was similar to that of hydrochloro thiazide (moderate efficacy diuretic). However, further evaluation is required to understand the molecular mechanism, and site of action of Moringa oleifera. The results were statistically analysed and proved to be significant. Hence Moringa oleifera possess diuretic (moderate efficacy) effect.

Funding: No funding sources Conflict of interest: None declared

Ethical approval: The study was approved by the Institutional Ethics Committee

\section{REFERENCES}

1. Cannachie AM. Diuretic treatment, In: John Feely, New Drugs, Third edition, Oxford University Press, New Delhi, 1994. pp. 127-143.

2. Goddard. Kidney and urinary tract disease, Nicholas A. Boon et al., Davidson's Principles and Practice of Medicine, 20th edition, Churchill Livingstone, New York, 2006. pp. 480-481.

3. Jackson EK. Diuretics, In: Brunton LL. (eds) Goodman and Gillman's, The pharmacological Basis of therapeutics, Eleventh edition, McGraw Hill, New York 2006. pp. 737-767.

4. Ives HE. Diuretic Agents, In: Katzung BG. (eds) Basics and clinical pharmacology, 10th edition, Mc Graw Hill, New York 2007. pp. 236-253.

5. Patwardhan B. Traditional Medicine. Herbal drugs: A twenty first century perspectives, First edition Jaypee Brothers, New Delhi 2006. pp. 18-19.

6. Gadge KRV. Anti-Arthritic Activity of extracts of Moringa oleifera lam. Roots, Indian drugs, Scientific 
and Research Publication from Indian drugs manufacturer's Association, 2006;43(7):543-6.

7. Fernandes EE, Pulwale AV, Patil GA, Moghe AS. Probing regenerative potential of Moringa oleifera aqueous extracts using In vitro cellular assays. Phcog Res. 2016;8:231-7.

8. Vithal SB. Extrapolation of findings from animal to man with special reference to diuretics. In: Indian Journal of pharmacology. 1973;5(4):22-4.

9. Caceres. Pharmacologic properties of Moringa oleifera J. Ethno pharmacol. 1992;36(3):233-7.

10. Berkovich. Moringa Oleifera aqueous leaf extract downregulates nuclear factor-kappaB and increases cytotoxic effect of chemotherapy in pancreatic cancer cells. BMC
Complementary and Alternative Medicine. 2013;13:224-8.

11. Sujatha S. Anti-inflammatory activity of aqueous extract of emblica officinalis in animal models of inflammation. Indian $\mathbf{J}$ Pharmacol. Abstracts of 38th Annual Conference. 2005;37-S5.

12. Anwar F, Latif S, Ashraf M, Gilani AH. Moringa oleifera: a food plant with multiple medicinal uses. Phytother Res. 2007;21(1):17-25.

13. Frenkel NJ, Vogt L, De Rooij SE, Trimpert C, Levi MM, Deen PM, van den Born BJ. Thiazide-induced hyponatraemia is associated with increased water intake and impaired urea-mediated water excretion at low plasma antidiuretic hormone and urine aquaporin-2. J Hypertens. 2015;33(3):627-33.

Cite this article as: Hema SK Lourdu JA. Diuretic effect of chloroform seed extract of Moringa oleifera (Linn.) in Wistar rats. Int $\mathrm{J}$ Basic Clin Pharmacol 2016;5:2561-5. 